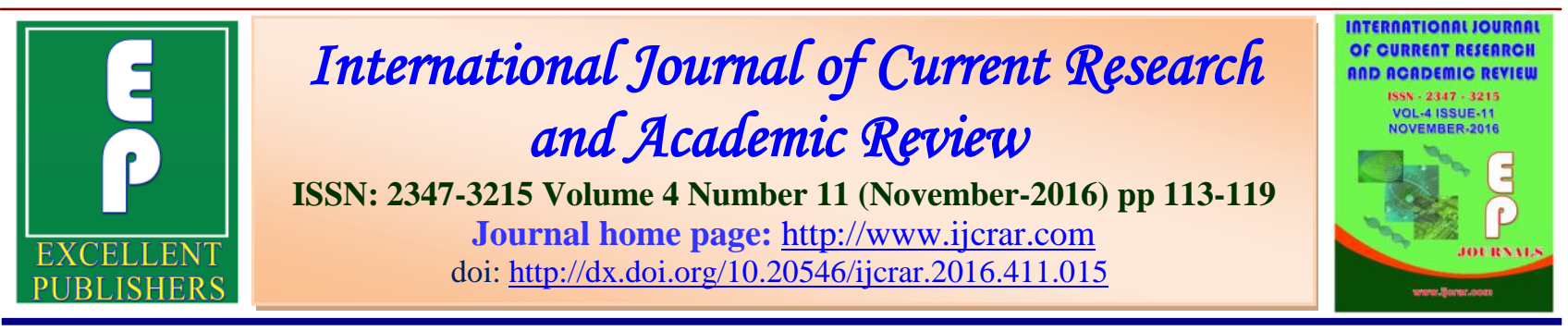

\title{
Ethnobotanical Studies of Interior Area of Aligarh District (U.P.), India
}

\section{Yogendra Singh*}

Department of Botany, Divya Nand Vidyamandir Mahavidyalaya, Sandila, Hardoi, India

\section{*Corresponding author}

\section{KEYWORDS}

Aligarh district, ethnobotany, ethnomedicine, phytoremedy, Traditional use.

\section{A B $\mathbf{S}$ T $\mathbf{R}$ A $\mathbf{C}$ T}

From ancient times, the plants have been used as sources of medicines by the tribal or human being. However, information on the uses of plants medicine was lacking from many interior areas of Aligarh district. Visits were carried out in different areas for getting the information. The observation revealed that the local and rural communities use many plants in various common ailments like bronchitis, boil, tumor, cold and cough etc. in Aligarh district. These communities prepared polyhedral drugs either singly or in combination with other plant species. They have been using such preparations for a long time for human healthcare.

\section{Introduction}

Most of the village people are poor, so the rural people largely depend on the traditional herbal medicines prepared by practitioners. Types of practitioners are vaidh, kaviraj, hakim etc. They depend on various ethnomedicinal plants. They visit the field from village to village for collecting the ethnomedicinal plants weekly and use them in various diseases. Almost every village has either one or two vaidh or hakim. Mostly practitioners are not well educated but they are very experienced in their field. The main objects of the survey were to collect the ethnomedicinal information of plants from interior area of Aligarh district (U.P.).

\section{Materials and Methods}

The ethnobotanical informations were collected during regular field trips through interviews and discussions with herbal medicine practitioners locally called as 'Vaidhya', 'Hakim', 'Kabiraj' and other experienced old men. While noting the information, every care was taken to record the local name of plants, flowering \& fruiting time, part used, method of drug preparation and their uses. The modes of application of the different plant species were different for the treatment of various common diseases. Plant species were identified by using relevant flora (Duthie, 1903-1929), (Bennet, 1987). 
The ethnomedicinal use of the plants were compared with available Scientific Literatures (Amiri and Joharchi 2012), (Bhatt and Gaur, 1992), 929, 1973), (Hooker, 1875-1897), (Islam, 2000), (Katewa et al., 2001), (Khanna, et al., 1996), (Kumar and Chauhan, 2005), (Pandey and Kumar, 2006), (Saini, 1996).

\section{Results and Discussion}

In the present study it is observed that the use of the plants is generally depended upon the availability of those plants near their villages. Analysis of the data reveals that the plant species are employed for the treatment of bronchitis, boil, tumor, cough and cold etc. The ethnomedicinal informations regarding treatment of various diseases have been collected during the survey of Aligarh district (U.P.). It is presented here in tabular form (Table-1). 50 ethnomedicinal plant species belonging to 30 families and 47 genera are enumerated in the present work. 40 plant species and 10 plant species are used for single drug treatments and multidrug treatment respectively. All plant species have been arranged alphabetically with botanical name, family, local name, flowering \& fruiting time, parts used, disease and mode of use. In the present study, out of 50 families, Amaranthaceae, Caesalpiniaceae and Liliaceae are mostly used in the treatment of various diseases. Leaf constitute is the highest (24) of utilization followed by stem (13), seed (8), root (11), whole plant (7), flower (4) bulb (2) and fruit (2).

Table.1 Result of field survey

\begin{tabular}{|c|c|c|c|c|}
\hline $\begin{array}{l}\text { Botanical name, family and } \\
\text { local name }\end{array}$ & $\begin{array}{l}\text { Fls / Frts } \\
\text { Time }\end{array}$ & $\begin{array}{l}\text { Part } \\
\text { used }\end{array}$ & Disease & Preparation and mode of use \\
\hline $\begin{array}{l}\text { Abrus precatorius L. } \\
\text { Fabaceae (Leguminosae) } \\
\text { "Ghumch". }\end{array}$ & $\begin{array}{l}\text { Aug-Sep/ } \\
\text { Sep-oct }\end{array}$ & $\begin{array}{l}\text { Leaf } \\
\text { Root }\end{array}$ & $\begin{array}{l}\text { Bronchitis } \\
\text { Cold \& } \\
\text { cough }\end{array}$ & $\begin{array}{l}\text { Fifteen to twenty leaves are crushed in water } \\
\text { and warmed for some time to prepared } \\
\text { decoction. Decoction is given to the patient in } \\
\text { the case of cold \& cough twice in a day. } \\
\text { Leaf powder ( } 1-3 \text { grams) is given to the } \\
\text { patient of the bronchitis. } \\
\text { Roots are crushed and squeezed to get the root } \\
\text { extract. The root extract is useful to getting } \\
\text { the relief in obstinate cough and cold. }\end{array}$ \\
\hline $\begin{array}{l}\text { Acacia catechu L. } \\
\text { (Mimosaceae), } \\
\text { "Cattha". }\end{array}$ & $\begin{array}{l}\text { Jul-Aug/ } \\
\text { Sep-Mar }\end{array}$ & Bark & $\begin{array}{l}\text { cold \& } \\
\text { cough }\end{array}$ & $\begin{array}{l}\text { Decoction or powder of Bark is used as a } \\
\text { gargling solution. }\end{array}$ \\
\hline $\begin{array}{l}\text { Acacia nilotica } \mathrm{L} . \\
\text { (Mimosaceae), } \\
\text { "Babul". }\end{array}$ & $\begin{array}{l}\text { Jul-Oct/ } \\
\text { Nov-Feb }\end{array}$ & Bark & $\begin{array}{l}\text { Whooping } \\
\text { cough }\end{array}$ & $\begin{array}{l}15-100 \text { grams stem`s bark decoction is } \\
\text { prepared in water with a small quantities of } \\
\text { salt and jaggery (local name Gur, solidified } \\
\text { sugarcane). One teaspoon of decoction is } \\
\text { given twice a day in cold and whooping } \\
\text { cough. }\end{array}$ \\
\hline $\begin{array}{l}\text { Achyranthus aspera L. } \\
\text { (Amaranthaceae), } \\
\text { "Chirchitta". }\end{array}$ & $\begin{array}{l}\text { For most } \\
\text { part of year }\end{array}$ & $\begin{array}{l}\text { Whole } \\
\text { Leaf }\end{array}$ & $\begin{array}{l}\text { Cold \& } \\
\text { cough } \\
\text { Boil, Tumor }\end{array}$ & $\begin{array}{l}\text { One teaspoonful plant extract added with half } \\
\text { amount of honey is given in cold \& cough to } \\
\text { patient. } \\
\text { Leaf juice is made without admixture of water. } \\
\text { This juice is being used as an ointment to treat } \\
\text { boils and tumors. }\end{array}$ \\
\hline
\end{tabular}


Int.J.Curr.Res.Aca.Rev.2016; 4(11): 113-119

\begin{tabular}{|c|c|c|c|c|}
\hline $\begin{array}{l}\text { Adhatoda vesica Nees. } \\
\text { (Acanthaceae), } \\
\text { "Piyabans". }\end{array}$ & $\begin{array}{l}\text { Oct-Jan/ } \\
\text { Jan-Mar }\end{array}$ & $\begin{array}{l}\text { Leaf \& } \\
\text { Flower }\end{array}$ & Bronchitis & $\begin{array}{l}\text { Leaf or flower juice or extract }(15-20 \mathrm{ml}) \text { are } \\
\text { given to the patient in the case of bronchitis. }\end{array}$ \\
\hline $\begin{array}{l}\text { Ageratum conyzoides } \mathrm{L} \text {. } \\
\text { (Asteraceae); } \\
\text { 'Sarhand' }\end{array}$ & $\begin{array}{l}\text { Jan-Mar/ } \\
\text { Mar-Apr }\end{array}$ & Leaf & Boil & $\begin{array}{l}\text { Lukewarm past prepared from leaves is } \\
\text { applied as poultice on the boils for healing. }\end{array}$ \\
\hline $\begin{array}{l}\text { Allium cepa } \mathrm{L} . \\
\text { (Liliaceace), } \\
\text { "Piyaj". }\end{array}$ & Jun- Aug & Bulb & $\begin{array}{l}\text { Tumor } \\
\text { Bronchitis } \\
\text { Cold \& } \\
\text { cough }\end{array}$ & $\begin{array}{l}\text { Lukewarm pulp of the bulb is bandaged on } \\
\text { tumors for getting relief. } \\
\text { Boiled 3-5 crushed garlic cloves are given } \\
\text { along with lukewarm milk daily at night in } \\
\text { case of bronchitis. } \\
\text { Bulb juice mixed with a little hing (dried latex } \\
\text { of Ferula assafoetida) is given orally in case } \\
\text { of cold \& cough. }\end{array}$ \\
\hline $\begin{array}{l}\text { Allium sativum } \mathrm{L} . \\
\text { (Liliaceace), } \\
\text { "Lahsun". }\end{array}$ & Jun- Aug & Bulb & $\begin{array}{l}\text { Cold \& } \\
\text { cough }\end{array}$ & $\begin{array}{l}\text { One bulb ground with } 50 \text { gram seed oil of } \\
\text { arund (Ricinus cummunis) is boiled. The oil is } \\
\text { massaged on the chest to cure cold \& cough. }\end{array}$ \\
\hline $\begin{array}{l}\text { Aloe vera (Linn.)Burm.f. } \\
\text { (Liliaceae), } \\
\text { "Ghinkwar". }\end{array}$ & $\begin{array}{l}\text { End of } \\
\text { winter }\end{array}$ & Leaf & Tumor & $\begin{array}{l}\text { A poultice prepared from the leaves is applied } \\
\text { externally on tumors for getting relief. }\end{array}$ \\
\hline $\begin{array}{l}\text { Alstonia scholaris L. } \\
\text { (Apocynaceae), } \\
\text { "Chitwan". }\end{array}$ & Winter & $\begin{array}{l}\text { Latex } \\
\text { Leaf }\end{array}$ & $\begin{array}{l}\text { Boil } \\
\text { Boil }\end{array}$ & $\begin{array}{l}\text { Stem latex is used externally over the boils } \\
\text { twice a day for three days. } \\
\text { The fresh leaf past with small amount of honey } \\
\text { is applied on boil for whole night. }\end{array}$ \\
\hline $\begin{array}{l}\text { Amaranthus spinosus L. } \\
\text { (Amaranthaceae), } \\
\text { "Kantachouli". }\end{array}$ & Aug-Jan & $\begin{array}{l}\text { Leaf \& } \\
\text { Root } \\
\text { Stem }\end{array}$ & $\begin{array}{l}\text { Boil, } \\
\text { Boil }\end{array}$ & $\begin{array}{l}\text { Past prepared by leaves and roots are applied } \\
\text { externally as poultice on boils. } \\
\text { The past prepared by ash of dry stem and some } \\
\text { amount of lime is applied on the mature boil } \\
\text { for bursting soon. }\end{array}$ \\
\hline $\begin{array}{l}\text { Amaranthus viridis Hook. } \\
\text { (Amaranthaceae), } \\
\text { "Jangali Chouli". }\end{array}$ & July-Feb & Root & Boil & $\begin{array}{l}\text { Root paste is applied externally on the boils } \\
\text { for getting relief in pain. }\end{array}$ \\
\hline $\begin{array}{l}\text { Argemone mexicana } \mathrm{L} . \\
\text { (Papaveraceae), } \\
\text { "Pili Kateli". }\end{array}$ & $\begin{array}{l}\text { Oct-Apr/ } \\
\text { Apr-May }\end{array}$ & Seed & $\begin{array}{l}\text { Whooping } \\
\text { cough }\end{array}$ & $\begin{array}{l}\text { Whole plant crushed and ground in water is } \\
\text { filtered. The filtrate is boiled and again with } \\
\text { clean cloth. Only two teaspoonful brownish } \\
\text { decoction is given once a day for three to four } \\
\text { days for the treatment of whooping cough. } \\
\text { Seed oil is applied externally on boil for } \\
\text { getting relief. }\end{array}$ \\
\hline $\begin{array}{l}\text { Azadirachta indica A. } \\
\text { Juss. (Meliaceae), } \\
\text { "Neem". }\end{array}$ & $\begin{array}{l}\text { Mar-May/ } \\
\text { May-Jun }\end{array}$ & Leaf & Boil, Tumor & $\begin{array}{l}\text { Leaf extract is applied externally on the boil } \\
\text { and tumor for curing and healing soon. }\end{array}$ \\
\hline $\begin{array}{l}\text { Bacopa monnieri L. } \\
\text { (Scrophuliaceae), } \\
\text { "Vermin". }\end{array}$ & $\begin{array}{l}\text { Aug-Oct/ } \\
\text { Oct-Nov }\end{array}$ & Whole & Bronchitis & $\begin{array}{l}\text { Lukewarm juice of Bacopa monnieri is applied } \\
\text { or massaged on the chest of the children in } \\
\text { bronchitis }\end{array}$ \\
\hline $\begin{array}{l}\text { Bauhinia purpurea L. } \\
\text { (Caesalpiniaceae), } \\
\text { "Kachnar". }\end{array}$ & $\begin{array}{l}\text { Nov-Feb./ } \\
\text { Mar-Apr }\end{array}$ & Bark & $\begin{array}{l}\text { cold \& } \\
\text { cough } \\
\text { Boil. }\end{array}$ & $\begin{array}{l}\text { About } 10 \mathrm{ml} \text { root decoction is given along with } \\
\text { one glass of lukewarm water twice a day for 5- } \\
7 \text { days in case of cold \& cough. } \\
\text { Bark decoction mixed with gur (jeggery) is } \\
\text { lopped on the boils and wounds to wash and }\end{array}$ \\
\hline
\end{tabular}


Int.J.Curr.Res.Aca.Rev.2016; 4(11): 113-119

\begin{tabular}{|c|c|c|c|c|}
\hline & & & & heal. \\
\hline $\begin{array}{l}\text { Bryophyllum pinnatum } \\
\text { Lamk. (Crassulaceae), } \\
\text { "Zakhmhayat". }\end{array}$ & & Leaf & Boil, Tumor & $\begin{array}{l}\text { Lukewarm leaf past is applied externally on } \\
\text { the boils and tumors of the body. }\end{array}$ \\
\hline $\begin{array}{l}\text { Butea monosperma Lamk. } \\
\text { (Fabaceae), } \\
\text { "Dhak". }\end{array}$ & Mar-May & Stem & Bronchitis & $\begin{array}{l}\text { Leaf juice mixed with curd and a pinch of } \\
\text { haldi powder (turmeric powder) is applied } \\
\text { externally on the boil. } \\
\text { The decoction prepared form shoot is taken in } \\
\text { the case of bronchitis. }\end{array}$ \\
\hline $\begin{array}{l}\text { Carissa spinarum Hook. } \\
\text { (Apocynaceae), } \\
\text { "Karaunda". }\end{array}$ & $\begin{array}{l}\text { Nov-Dec/ } \\
\text { Dec-Feb }\end{array}$ & Leaf & $\begin{array}{l}\text { Whooping } \\
\text { cough. }\end{array}$ & $\begin{array}{l}\text { One teaspoonful of leaves extract is given in } \\
\text { whooping cough with honey twice a day. }\end{array}$ \\
\hline $\begin{array}{l}\text { Cleome viscosa } \mathrm{L} \text {. } \\
\text { (Capparidaceae), } \\
\text { "Hulhul" }\end{array}$ & $\begin{array}{l}\text { Jul-Sep/ } \\
\text { Sep-Oct }\end{array}$ & Leaf & Boil. & $\begin{array}{l}\text { Leaf past is applied externally on boils to } \\
\text { prevent pus formation. }\end{array}$ \\
\hline $\begin{array}{l}\text { Coriandrum sativum } \mathrm{L} . \\
\text { (Apiaceae), } \\
\text { "Dhania". }\end{array}$ & Jan-Mar & $\begin{array}{l}\text { Whole } \\
\text { Seed }\end{array}$ & Cold & $\begin{array}{l}\text { Plant is ground in water of rice is given to the } \\
\text { patient thrice a day for three to four days. } \\
\text { Two to three teaspoonful seeds are boiled in } \\
\text { half liter of water with adding some sugar } \\
\text { according to test until } 100 \mathrm{ml} \text { remains. It is } \\
\text { given to patient in cold. }\end{array}$ \\
\hline $\begin{array}{l}\text { Curcuma longa } \mathrm{L}, \\
\text { (Zingiberaceae), } \\
\text { "Haldi". }\end{array}$ & - & Stem & $\begin{array}{l}\text { Cough \& } \\
\text { Bronchitis. }\end{array}$ & $\begin{array}{l}\text { One spoonful juice obtained from the rhizome } \\
\text { mixed with equal amount of honey is given } \\
\text { orally twice a day for a long time. }\end{array}$ \\
\hline $\begin{array}{l}\text { Datura metel L. } \\
\text { (Solanaceae), "Datura". }\end{array}$ & Dec-Jun & Leaf & Boil, Tumor & $\begin{array}{l}\text { Luke warm leaves are bandaged on the boils } \\
\text { and ulcers. }\end{array}$ \\
\hline $\begin{array}{l}\text { Eclipta prostrata } \mathrm{L} . \\
\text { (Asteraceae), } \\
\text { "Kala Bhangra". }\end{array}$ & $\begin{array}{l}\text { Most part } \\
\text { of year }\end{array}$ & Leaf & Cough & $\begin{array}{l}\text { Leaf extract or juice }(10 \mathrm{ml}) \text { mixed with equal } \\
\text { amount of honey are given to orally early in } \\
\text { the morning for } 3 \text { days. }\end{array}$ \\
\hline $\begin{array}{l}\text { Eucalyptus glabulus Labill. } \\
\text { (Myrtaceae), } \\
\text { "Safeda". }\end{array}$ & May-Jun & Leaf & Bronchitis. & $\begin{array}{l}\text { Leaves are boiled in water and inhaled as a } \\
\text { respiratory antiseptic in bronchitis. }\end{array}$ \\
\hline $\begin{array}{l}\text { Evolvulus alsinoides L. } \\
\text { (Convolvulaceae), } \\
\text { "Vishnukrantha". }\end{array}$ & $\begin{array}{l}\text { Aug-Oct/ } \\
\text { Oct-Nov }\end{array}$ & Leaf & Bronchitis. & $\begin{array}{l}\text { Leaves are used as cigarettes in bronchitis for } \\
\text { getting the relief. }\end{array}$ \\
\hline $\begin{array}{l}\text { Ficus religiosa } \mathrm{L} . \\
\text { (Moraceae), } \\
\text { "Pipal". }\end{array}$ & Mar-May & Bark & $\begin{array}{l}\text { Whooping } \\
\text { cough. }\end{array}$ & $\begin{array}{l}\text { Bark decoction ( } 50-100 \mathrm{ml}) \text { is given orally } \\
\text { thrice a day for curing whooping cough. }\end{array}$ \\
\hline $\begin{array}{l}\text { Holoptelea integrifolia } \\
\text { Hook. } \\
\text { (Ulmaceae), "Papri". }\end{array}$ & Feb.-Apr & Seed & Boil, Tumor & $\begin{array}{l}\text { Seed kernels are fried into oil of Sesamum } \\
\text { indicum. The filtered oil is applied externally } \\
\text { on the boils and tumors. }\end{array}$ \\
\hline $\begin{array}{l}\text { Leucas cephalotus Hook. } \\
\text { (Lamiaceae), "Gubha". }\end{array}$ & $\begin{array}{l}\text { Aug-Oct/ } \\
\text { Oct-Nov }\end{array}$ & Flower & $\begin{array}{l}\text { Cold \& } \\
\text { cough }\end{array}$ & $\begin{array}{l}\text { Syrup is prepared from Flowers. It is given as } \\
\text { a domestic remedy for cold \& cough. }\end{array}$ \\
\hline $\begin{array}{l}\text { Linum usitatissimum L. } \\
\text { (Linaceae), "Alsi". }\end{array}$ & $\begin{array}{l}\text { Jan-Feb/ } \\
\text { Feb-Mar }\end{array}$ & Seed & $\begin{array}{l}\text { Cold \& } \\
\text { cough }\end{array}$ & $\begin{array}{l}\text { Seeds powder mixed with honey is given with } \\
\text { lukewarm water in cold \& cough. }\end{array}$ \\
\hline $\begin{array}{l}\text { Nerium indicum Hook. } \\
\text { (Apocynaceae), } \\
\text { "Kaner" }\end{array}$ & $\begin{array}{l}\text { Jun-Jul/ } \\
\text { Jul-Sep }\end{array}$ & Latex & Boil. & $\begin{array}{l}\text { Stem latex is applied externally over the boil } \\
\text { twice a day for about ten days. }\end{array}$ \\
\hline $\begin{array}{l}\text { Ocimum sanctum L. Mant. } \\
\text { (Lamiaceae), }\end{array}$ & Feb-May & Flower & $\begin{array}{l}\text { Cold \& } \\
\text { cough. }\end{array}$ & $\begin{array}{l}\text { Lukewarm flowers extract with honey, ginger } \\
\text { (rhizome of Zingeber officinale) and onion }\end{array}$ \\
\hline
\end{tabular}


Int.J.Curr.Res.Aca.Rev.2016; 4(11): 113-119

\begin{tabular}{|c|c|c|c|c|}
\hline "Tulsi". & & $\begin{array}{l}\text { Leaf } \\
\text { Leaf }\end{array}$ & $\begin{array}{l}\text { Bronchitis } \\
\text { cold \& } \\
\text { cough. } \\
\text { Whooping } \\
\text { cough. }\end{array}$ & $\begin{array}{l}\text { juice (Allium cepa) are being used in common } \\
\text { cold \& cough. } \\
\text { One cup of tea prepared by adding the } 15-25 \\
\text { leaves is given thrice in a day in case of } \\
\text { bronchitis and cold \& cough. } \\
\text { Leaf juice is mixed with honey and is given } \\
\text { orally in whooping cough. }\end{array}$ \\
\hline $\begin{array}{l}\text { Opuntia delleni Hook. } \\
\text { (Cactaceae), } \\
\text { "Nagphani". }\end{array}$ & Mar-Apr & Stem & Boil & $\begin{array}{l}\text { Lukewarm pulp of the stem is applied } \\
\text { externally on boils. }\end{array}$ \\
\hline $\begin{array}{l}\text { Phaseolus mungo L. } \\
\text { (Fabaceae), } \\
\text { "Urd". }\end{array}$ & $\begin{array}{l}\text { Jan-Feb/ } \\
\text { Mar-Apr }\end{array}$ & Seed & Boil,Tumor & $\begin{array}{l}\text { About } 4 \text { gram ripe seeds are crushed and } \\
\text { mixed with equal amount of guana of pigeon } \\
\text { and applied over the boil for two days in night } \\
\text { just before going to bed. } \\
\text { Seed powder is rubbed into scarifications over } \\
\text { tumors and abscesses to promote exudation. }\end{array}$ \\
\hline $\begin{array}{l}\text { Phyla nudiflora L. } \\
\text { (Verbenaceae); "Bukkan", }\end{array}$ & Mar-Sep & Whole & Boil. Tumor & $\begin{array}{l}\text { Paste or poultice of fresh plant is applied } \\
\text { externally to boils and tumor. }\end{array}$ \\
\hline $\begin{array}{l}\text { Plumbago zeylanica } \mathrm{L} . \\
\text { (Plumbaginaceae), } \\
\text { "Chirchitta". }\end{array}$ & $\begin{array}{l}\text { Oct-Jan/ } \\
\text { Jan-Feb }\end{array}$ & $\begin{array}{l}\text { Leaf } \\
\text { Whole }\end{array}$ & $\begin{array}{l}\text { Boil, } \\
\text { Boil. }\end{array}$ & $\begin{array}{l}\text { Lukewarm leaf is tied on the boils by cotton } \\
\text { cloth to reduce them soon. } \\
\text { Plant paste is applied as poultice on mature } \\
\text { boils and tumors. They are busted and come } \\
\text { out. }\end{array}$ \\
\hline $\begin{array}{l}\text { Pongamia pinnata (L.) } \\
\text { Pierre. } \\
\text { Syn. Cytisus pinnatus L. } \\
\text { (Fabaceae), "Papri". }\end{array}$ & $\begin{array}{l}\text { Mar-May/ } \\
\text { May-Jun }\end{array}$ & Seed & $\begin{array}{l}\text { Whooping } \\
\text { cough }\end{array}$ & $\begin{array}{l}\text { Seed powder (1-3 grams) is given along with } \\
\text { lukewarm milk in the case of whooping cough. }\end{array}$ \\
\hline $\begin{array}{l}\text { Rungia repens }(\mathrm{L} .) \text { Nees. } \\
\text { (Acanthaceae), }\end{array}$ & Oct-Jan & Whole & Cough. & $\begin{array}{l}\text { Whole dried plant is crushed and given in } \\
\text { doses of } 4-12 \text { gram along with lukewarm tea } \\
\text { in cough. }\end{array}$ \\
\hline $\begin{array}{l}\text { Salvadora persica } \mathrm{L} \text {. } \\
\text { (Salvadoraceae), } \\
\text { "Pilu". }\end{array}$ & $\begin{array}{l}\text { Nov-Feb/ } \\
\text { Feb-Mar }\end{array}$ & Leaf & $\begin{array}{l}\text { Cough, } \\
\text { Tumor, } \\
\text { Bronchitis. }\end{array}$ & $\begin{array}{l}\text { Leaf decoction }(50-100 \mathrm{ml}) \text { is given in cough. } \\
\text { Leaf past is applied externally as a poultice on } \\
\text { tumors. } \\
\text { Leaf juice }(60-80 \mathrm{ml}) \text { is given orally in the } \\
\text { case of bronchitis. The smoke of the fruit is } \\
\text { also inhale. }\end{array}$ \\
\hline $\begin{array}{l}\text { Solanum xanthocarpum } \\
\text { Schrad. } \\
\text { (Solanaceae), } \\
\text { "Kateri". }\end{array}$ & $\begin{array}{l}\text { May-Aug/ } \\
\text { Aug-Sep }\end{array}$ & $\begin{array}{l}\text { Flower } \\
\text { Fruit, } \\
\text { Root }\end{array}$ & $\begin{array}{l}\text { Whooping } \\
\text { cough } \\
\text { Cold \& } \\
\text { cough. } \\
\text { Cough. }\end{array}$ & $\begin{array}{l}\text { Half gram of dried flower powder is mixed } \\
\text { with honey and licked to relieve whooping } \\
\text { cough } \\
\text { Power of dried fruit mixed with honey is given } \\
\text { to children in the case of cold \& cough. } \\
\text { Root decoction mixed with long pepper } \\
\text { (flowering vine of Piper longum, Piperaceae) } \\
\text { and honey is given orally in cough. }\end{array}$ \\
\hline $\begin{array}{l}\text { Tamarindus indica } \mathrm{L} . \\
\text { (Caesalpiniaceae), } \\
\text { "Imli". }\end{array}$ & $\begin{array}{l}\text { Jul-Sep/ } \\
\text { Sep-Nov }\end{array}$ & Seed & $\begin{array}{l}\text { Cold \& } \\
\text { cough }\end{array}$ & $\begin{array}{l}\text { Seed past is applied to forehead in the case of } \\
\text { cold \& cough for getting the relief. }\end{array}$ \\
\hline $\begin{array}{l}\text { Terminalia arjuna Roxb. } \\
\text { (Combretaceae), } \\
\text { "Arjun". }\end{array}$ & $\begin{array}{l}\text { May-Jun/ } \\
\text { Jul-Aug }\end{array}$ & Bark & Boil & $\begin{array}{l}\text { Bark powder (4 gram) mixed with the leaf } \\
\text { juice }(10 \mathrm{ml}) \text { of Adhatoda vesica, ghee and } \\
\text { honey is given twice a day for about two }\end{array}$ \\
\hline
\end{tabular}


Int.J.Curr.Res.Aca.Rev.2016; 4(11): 113-119

\begin{tabular}{|c|c|c|c|c|}
\hline & & Leaf & Boil & $\begin{array}{l}\text { weeks. } \\
\text { Four gram leaf extract is given orally thrice in } \\
\text { a day for about two weeks. }\end{array}$ \\
\hline $\begin{array}{l}\text { Thevatia peruviana (Pers.) } \\
\text { Merr., (Apocynaceae), } \\
\text { "Pili Kanner". }\end{array}$ & $\begin{array}{l}\text { Mar-Apr/ } \\
\text { Apr-May }\end{array}$ & Root & Tumor & $\begin{array}{l}\text { Root past is applied as poultice externally on } \\
\text { tumors and also bandaged by the cotton cloths. }\end{array}$ \\
\hline $\begin{array}{l}\text { Tribulus terristris L. } \\
\text { (Zygophyllaceae), } \\
\text { "Gokhru". }\end{array}$ & $\begin{array}{l}\text { Jul-Sep/ } \\
\text { Sep-Nov }\end{array}$ & Fruit & Bronchitis & $\begin{array}{l}\text { Fruit powder ( } 3-6 \text { gram) or root decoction is } \\
\text { given twice a day in the cases of bronchitis. }\end{array}$ \\
\hline $\begin{array}{l}\text { Trigonella foenum- } \\
\text { graecum } \mathrm{L} \text {. } \\
\text { (Caesalpiniaceae),"Methi”. }\end{array}$ & $\begin{array}{l}\text { Jan-Mar/ } \\
\text { Feb-Mar }\end{array}$ & Seed & Boil, Tumor & $\begin{array}{l}\text { Seed past is applied externally as a poultice on } \\
\text { the boils and tumor for healing. }\end{array}$ \\
\hline $\begin{array}{l}\text { Triumfetta rhomboidea } \\
\text { Jacq. (Tiliaceae), } \\
\text { "Kasni". }\end{array}$ & $\begin{array}{l}\text { Aug-Sep/ } \\
\text { Sep-Oct }\end{array}$ & $\begin{array}{l}\text { Root } \\
\text { Root } \\
\text { Stem \& } \\
\text { leaf }\end{array}$ & $\begin{array}{l}\text { Boil, Tumor } \\
\text { Bronchitis } \\
\text { Boil, Tumor }\end{array}$ & $\begin{array}{l}\text { Root extract mixed with the beet (feaces) of } \\
\text { pigeons is applied on the boils and tumors for } \\
\text { bursting soon. } \\
\text { Root extract is boiled and strained. The filtrate } \\
\text { is given orally to the patient in bronchitis. } \\
\text { Pounded leaves and stem are being used } \\
\text { externally as a poultice on boils and tumors. }\end{array}$ \\
\hline $\begin{array}{l}\text { Vernonia cinerea } \mathrm{L} . \\
\text { (Asteraceae), } \\
\text { "Phulni". }\end{array}$ & $\begin{array}{l}\text { Sep-Feb/ } \\
\text { Feb-Mar }\end{array}$ & Root & $\begin{array}{l}\text { Cold \& } \\
\text { cough }\end{array}$ & $\begin{array}{l}\text { Root juice }(10-20 \mathrm{ml}) \text { is given orally to cure } \\
\text { cold and cough twice a day for about two } \\
\text { week. }\end{array}$ \\
\hline $\begin{array}{l}\text { Xanthium strumarium L. } \\
\text { (Asteraceae), } \\
\text { "Bhangra". }\end{array}$ & May-Mar & Root & Boil, Tumor & $\begin{array}{l}\text { Root extract is applied externally on the boils } \\
\text { and tumors for getting the relief in pain and to } \\
\text { heal. }\end{array}$ \\
\hline $\begin{array}{l}\text { Zingeber officinale } \mathrm{L} . \\
\text { (Zingiberaceae), } \\
\text { "Adarak" }\end{array}$ & - & Stem & Cough & $\begin{array}{l}\text { Lukewarm little root past mixed either with } \\
\text { honey or with ghee (clarified butter) is made } \\
\text { into pills, which is a good remedy against } \\
\text { cough. The pills ( } 3-4 \text { gram) are given for about } \\
\text { four days. } \\
\text { Rhizome (stem) past mixed with mustard oil is } \\
\text { applied externally on boils for getting relief. }\end{array}$ \\
\hline $\begin{array}{l}\text { Zizyphus rotundifolia } \\
\text { Lamk. } \\
\text { (Rhamnaceae), “Jhar Ber”. }\end{array}$ & $\begin{array}{l}\text { Jul-Sep/ } \\
\text { Sep-Dec }\end{array}$ & Leaf & $\begin{array}{l}\text { cold \& } \\
\text { cough }\end{array}$ & $\begin{array}{l}\text { Dried leaves are burnt and are inhaled in cold } \\
\& \text { cough. }\end{array}$ \\
\hline
\end{tabular}

\section{Conclusion}

The present study helped list out various ethnomedicinal plants. The paper provided here can be utilized to further studies on conservation and cultivation of ethnomedicinal plants of interior area of Aligarh district (U.P.). The youth should also be encouraged to learn the traditional medicinal knowledge to preserve it from being lost with the older generation. There is a need to take necessary steps for the conservation of plants and also for investigation chemically active principles and pharmaceuticals and medicinal evaluations.

\section{Acknowledgement}

The author is thankful to the practitioners and other experienced old men. I would like to thank my best friend Dr. Salendra kumar 
for suggesting the problem and for incessant help and exquisite guidance. Their tireless efforts, immense patience, motivation and lively discussion throughout the course of present investigation, made working with them an enjoyable experience.

\section{References}

Amiri, M.S., and Joharchi, M.R. 2012. Ethnobotanical investigation of traditional medicinal plants commercialized in the markets of Mashhad. Iran" Avicenna J Phytomed., Vol. 3(3): $254-271$.

Bennet, S.S.R. 1987. Name changes in Flowering Plants of India and adjacent regions. Triseas Publishers, Dehra Dun, India.

Bhatt, K.C., and Gaur, R.D. 1992. A contribution to ethnobotany of Rajasthan in Pithoragarh district. Acta. Bot. India, 20: 76 - 83.

Duthie, J.F. 1903-1929. Flora of the upper gangetic plain of the adjacent Siwalik and Sub-Himalayan tracts, Calcutta. 3 Vol.
Hooker, J.D. 1875-1897. Flora of British India. 7 vols. Reeve and Co., London, U. K.

Islam, M. 2000. Ethnobotany of bark of certain plants of North-East India. $J$. Econ. Taxon. Bot., 24(2): 419 - 432.

Katewa, S.S., B.L. Chaudhary, A. Jain. and Takhar, H.K. 2001. Some plants in folk medicine of Rajsamamd district (Rajasthan). Ethnobot, 13(1-2): 129 134.

Khanna, K.K., G. Shukla and Mudgal, V. 1996. New traditional medicinal uses of plants from Jalaun district, Uttar Pradesh. J. Econ. Taxon. Bot. Addl. Ser., 122: 108-111.

Kumar, S., and Chauhan, A.K.S. 2005. Medicinal plants used by local inhabitants in Bharatpur district, Rajasthan. Ethnobot., 17(1-2): 179-183.

Pandey, R.S., and Kumar, R.A. 2006. An ethnobotanical study in the Vindhyan Region, Uttar Pradesh. Indian J. For. 29(4): 389-394.

Saini, D.C. 1996. Ethnobotany of Tharus of basti district of Uttar Pradesh. J. Econ. Taxon. Bot. Addl. Ser., 12: 192 - 195.

\section{How to cite this article:}

Yogendra Singh. 2016. Ethnobotanical Studies of Interior Area of Aligarh District (U.P.), India. Int.J.Curr.Res.Aca.Rev.4(11): 113-119. doi: http://dx.doi.org/10.20546/ijcrar.2016.411.015 